\title{
Polski wkład w poznanie patofizjologii i anatomii tetralogii Fallota - praca Oskara Widmanna z 1881 roku
}

\author{
Ireneusz Haponiuk ${ }^{1}$, Janusz H. Skalski², Katarzyna Gierat-Haponiuk ${ }^{3}$ \\ ${ }^{1}$ Oddział Kardiochirurgii Dziecięcej Pomorskiego Centrum Traumatologii im. Mikołaja Kopernika w Gdańsku \\ ${ }^{2}$ Klinika Kardiochirurgii Dziecięcej Uniwersytetu Jagiellońskiego, Polsko-Amerykański Instytut Pediatrii \\ w Krakowie \\ ${ }^{3}$ Klinika Rehabilitacji Gdańskiego Uniwersytetu Medycznego
}

Kardiochirurgia i Torakochirurgia Polska 2012; 3: 391-393

Wrodzona wada serca określana powszechnie znanym terminem tetralogii Fallota była przedmiotem zainteresowania wielu badaczy, swą eponimiczną nazwę zawdzięcza zaś upowszechnieniu przez Maude Abbott nazwiska Étienne-Louisa Artura Fallota, autora publikacji w „Marseille Médical” w roku 1888 [1]. Zarówno przed Fallotem, jak i po jego publikacji powstawało wiele wartościowych prac na temat tetralogii, z których wiele mogłoby być źródłem nazwy dla przedmiotowej wady serca. W grupie badaczy i zbiorze opublikowanych współcześnie Fallotowi prac znajduje się także publikacja polskiego lekarza Oskara Widmanna, która poza tym, że opisuje wadę, o 7 lat wyprzedzając Fallota, stanowi najprawdopodobniej pierwszy w światowej literaturze naukowy opis innej wady towarzyszącej tetralogii - dwujamowej prawej komory. Pragniemy przybliżyć sylwetkę wybitnego polskiego lekarza, profesora medycyny Uniwersytetu Jagiellońskiego i Lwowskiego, który w roku 1881 wydał swoją najcenniejszą pracę Przypadek zwężenia tętnicy płucnej [2] (ryc. 1.). Znajomość sylwetki i historycznego dorobku Oskara Widmanna wydaje się cenna szczególnie w jego ojczyźnie, gdzie współcześnie epidemiologia, diagnostyka i leczenie tetralogii Fallota w ocenie wyników wczesnych, jak również odległych nie odbiega od najlepszych danych światowych.

Podążając zatem zgodnie z chronologią, wrodzona wada serca określana jako zespół Fallota (1850-1911) była przedmiotem zainteresowania E. Sandiforda z Lejdy i E. Gintraca (1791-1877), którzy przed Fallotem dokonali wcześniejszego opisania rzeczonej patologii. Mimo że znacznie wyprzedzili w tym względzie Fallota, na trwale zwyczajowo wiązanego z „zespołem” (tetralogią), także nie pośród nich należy doszukiwać się autora pierwszego opisu. Podaje się bowiem, że pierwszym był Nicolaus Steno (v. Niels Stensen - 1638-1686), który w 1671 r. opisywał swoje spostrzeżenie podobnej wady, co ciekawe - u noworodka obciążone- go ponadto ektopią serca, czyli wytrzewieniem poza obręb klatki piersiowej (z rozszczepem mostka). Jeszcze dwaj inni wielcy badacze wpisali się pośrednio w historię odkrycia „zespołu Fallota”, starając się powiązać przyczynowo ubytek międzykomorowy ze zwężeniem tętnicy płucnej. Byli to John William Hunter (1728-1793), który w 1783 r. pierwszy starał się wyjaśnić związek między zwężeniem tętnicy płucnej a obecnością ubytku w przegrodzie międzykomorowej serca - uważał mianowicie zwężenie tętnicy płucnej za pierwotne, natomiast ubytek za następstwo tej wady; oraz Johann Friedrich Meckel (1781-1833), który w 1812 r. wyraził odmienną opinię, że zwężenie tętnicy płucnej jest skutkiem, nie zaś przyczyną obecności ubytku międzykomorowego.

Podsumowując - chronologicznie autorami doniesień na temat „tetralogii” byli: Nikolaus Steno (1671 r.), Eduard Sandiford z Lejdy (1777 r.), J.W. Hunter (1783 r.), J.F. Meckel (1812 r.), E. Gintrac (1824 r.), J.P. Farré (1814 r. - zebrał 15 przypadków z piśmiennictwa), T.B. Peacock (1846 r.), Karl Rokitansky (1875 r.) oraz Étienne-Louis Artur Fallot (1888 r.) [3]. W swoim czasie, już w XX w., doceniając znaczenie pierwszego profesjonalnego raportu tej siniczej wady, proponowano nawet nazewnictwo „tetralogia Sandiforda”. Do mniej znanych, i niestety z rzadka cytowanych w piśmiennictwie, należy nazwisko polskiego lekarza Oskara Widmanna, wybitnego klinicysty ze Lwowa, który w 1881 r. opisał w niezwykle skrupulatny sposób swoje obserwacje kliniczne identycznej wady serca, prowadzone w latach 1874-1879, wzbogacone następnie o badanie sekcyjne. Opublikowanie w 1881 r. kazuistycznej pracy pt. Przypadek zwężenia tętnicy płucnej [2], która de facto dotyczyła pierwszego polskiego raportu na temat wady wrodzonej, współcześnie określanej zespołem Fallota, wyprzedziło o 7 lat doniesienie Fallota, obecnie niemal powszechnie, choć błędnie, traktowane jako pierwsze na temat tej szczególnej wady serca.

Adres do korespondencji: Ireneusz Haponiuk, Oddział Kardiochirurgii Dziecięcej, Pomorskie Centrum Traumatologii im. Mikołaja Kopernika, ul. Nowe Ogrody 1-6, 80-803 Gdańsk 


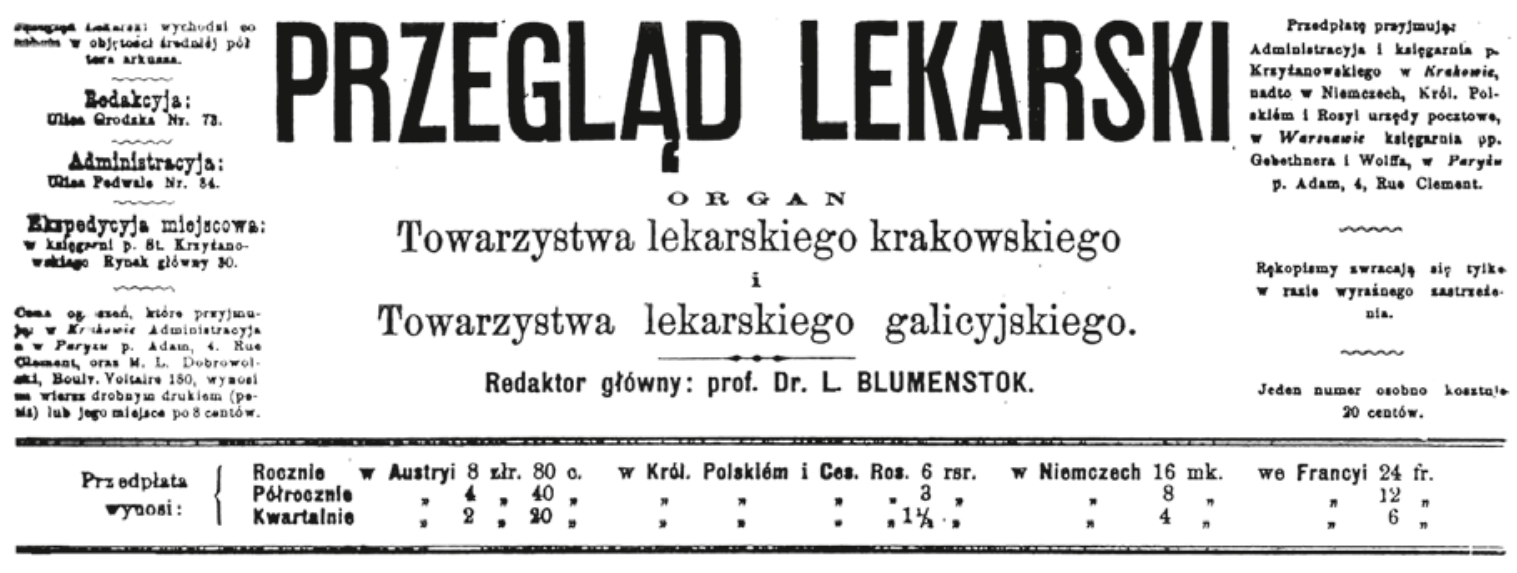

Krakiow, 3 wrzesnia $1881 . \quad$ Mr $36 . \quad$ Rok XX.

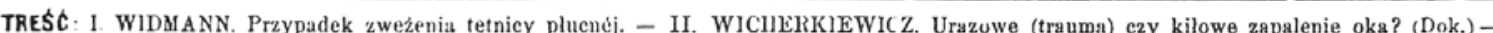
III Oceny i spraurydania. PIA SECCL. Stosunek hydroterapii do innych metod leczenia. SIMPSON and BERY HART (Edinburg):

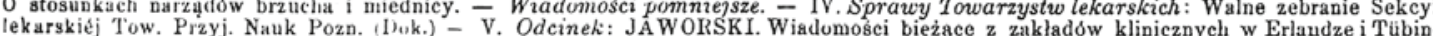
dza. (c. d.) - Vl. Wiadomoscr statystyczne $i$ ogólnolekarskie. - VIl. Wiadomosci bieżące.
alk $=$

\section{Przypadek zwężenia tętnicy płuenéj.}

Opisal Dr. O. Widmann.

Rzecz miana na III Zjeżdzio lekarzy i przyrodnıków polskich w Krakowie na dniu 21 lipca 1881.

W roku 1873 18go lutego przyjęto do szpitala powszechnego we Lwowio chłopaka stolarskiego, liczącego lat 14, który ciąnąa wózek na ulicy, padl bezprzytomny.

Jest on wzrostn wiekowi odpowiedniego, więzi dobrze rozwiniętéj, nadzwyczaj siny na twarzy i calém ciele; cieplota prawidlowa, kończyny chłodne, palce rąk paleczkowato zgrubiale. Przytomnosé utrzymana, odpowiedzi do rzeczy.

Klatka piersiowa wązka $\mathrm{i}$ dłaga, wypuk plue z obu stron prawidlowy, równiez przysluchem nie można stwierdzić zadnych zboczeú $w$ narządzie oddechania.

Po stronie lewéj klatki piersiowéj w okolicy sutka i na wewną̧trz od tegoz̀ widaé uderzenia serca na dośé rozleglém miejscu; koniec serca uderza w 5 tém międzyżebrzu na wewnatrz od sutka; tamźe daje się spostrzedz wyražne wciaganie skurczowe końca serca. W miejscu przyézepienia trzeeiego i czwartego zebra do lewego brzegu mostka wymacac się daje silny mruk skurczowy (fremissement systolique); nad końcem zas serca słychać cbropawy, szumiący szmer skurezowy, kończący sı̨̨ dość wysokim gwizdem, szmer ten wzmaga się w kierunku ku górze i ku lewemu brzegowi mostka, a jest najsilniéj słyszalny w trzeciem i ezwartém międzyżebrzu po stronie lewéj tuż obok i nieco na wewnątrz od lewego brzegu nostka. Szmer ten jest tak silny, ze go Z mniejszą lub większzą siłą usłyszeć možna. wzdluź caléj klatki piersiowèj. W tętnicach szyjnych słychać zamiast pierwszego tonu szmer, drugi ton jest dośc slaby i nieco gluchy. Ruzmiary serca 8ą w obu kierunkach, bardziéj jednak w kierunku poprzeeznym, nieco powiększone; ruchy serca nie są przyspieszone (80), umiarowe. Tętnica sprychowa mała, nocno ściągnięta.

Chory podaje, ze cierpi od urodzenia na zawroty glowy, które szczególnie przy wytężenin fizyczném czẹsciej i silniéj siç pojawiają. latwo się męczy i często miewa krwotoki z nosa.
Czując sie zresztą zupehnie zdrowym, opuścił dnia 21 lutego 1873 zaklad i powrocil do swego zawodu, lecz juź we dwa dni t. j. 23 lutego zostal przez policyję odstawiony do szpitala. Znaleziono go leźącego bez przytomności na ulicy; do dnia $7 \mathrm{go}$ marca, w którym wyszedł ze szpitala na własne ządanie, nie utracil przytomności.

22 marca zostal znowu z ulicy przyjęty, poniewał padl bezprzytomny; pozostawal do 16 kwietnia 1873 w zakładzie.

Przez czas ten mial kilkakrotnit krwotoki z nosa, spal prawie ciągle, rzucal się we śnie, tak iz musiano go umieścic w lózku dla chorych na padaczkę, tracil ezasami nagle na chwil kilka przytomnosé, siniejąc więcéj niź zwykle; sinica ta zwiększona utrzymywala się przez parę godzin po napadzie. Jakiego rodzaju te napady tyły, nie mogę opisać dokładnie, gdyż nigdy świadkiem ich nie bylem; z opisu wynika, ze chory tracil przytomność na krótki ezas i nagle, siniejąc przedtém mocniéj niž zwykle, toczył pianę $\mathrm{z}$ ust, dostawal drgawek, lecz nie krzyczał; po napadzie popadal w cięzki i niespokojny sen. O napadach nie wiedzial nic, ani téź nie mial zwiastunów; okazuje się z tego, ze napady te byly podobne do padaczkowych.

$\mathrm{Na}$ podstawie badania fizycznego powtórnego i obserwacyi kilkotygodniowéj rozpoznalem: $\mathrm{z}$ wężenie znaczne tętnicy plucnéj, prawdopodobnie wrodzone, z przypuszczeniem, ze istnieje otwor w przegrodzie pomiędzy komórami.

Od 16 go kwietnia 1873 do 14 go stycznia 1876 r. niewidzialem chorego, na dniu tym jednak wstąpiwszy do szpitala, nie opuścil go prawie przez cale 4 lata aź do śmierci, był bowiem przez teu ezas dwadzieścia kilka razy w zakladzie, przebywają̧ juz to po kilka dni lub tygodniami. Po raz ostatni przyjęty został na dniu 27 lipca 1879 i przebywal bez przerwy aż do śmierci, która w maju 1880 roku nastąpila.

W chwili przyjęcia, dnia 14go stycznia 1876 roku, skaržyl się na ból glowy, gorączkę i krwioplucie, które od trzech dni trwa.

Wyrósł od roku 1873 bardzo (ličy lat 1i); sinica na

Ryc. 1. Oryginat pracy Oskara Widmanna z $1881 \mathrm{r}$. 
Opis Oskara Widmanna nie ustępuje Fallotowskiemu, przewyższa go pragmatycznym spojrzeniem na przebieg kliniczny, jasnym i logicznym wywodem, wreszcie świetnie przeprowadzoną anatomopatologiczną analizą różnicową, z odniesieniem do klasyfikacji Rokitansky'ego (1804-1878). Charakter wady został oprócz tego prawidłowo określony za życia, a patologia zbadana po śmierci obserwowanego pacjenta. Widmann rozpoznał wadę przyżyciowo i to wiele lat wcześniej, w 1873 r. (u 14-letniego chłopca), obserwował pacjenta i leczył przez 7 lat, i dopiero po jego śmierci w 1880 r. mógł potwierdzić badaniem sekcyjnym rozpoznanie. Opis zarówno obserwacji klinicznej, jak i autopsji jest obszerny oraz bardzo precyzyjny. Oględziny serca potwierdziły diagnozę kliniczną, tj. zwężenie tętnicy płucnej (śr. 1 $\mathrm{cm}$, zastawka płucna była dwupłatkowa), ujawniły także obecność ubytku międzykomorowego: „[...] znachodzi się w tylnej części przegrody przedniej komory otwór półksiężycowy, od dołu wycięty, brzegi jego nie mają utkania ścięgnistego, również nacięty miąższ nie zdradza śladów zapalenia mięśnia. [...] Od góry otwór ten ograniczony w części wolnym brzegiem półksiężycowym, resztki przegrody błoniastej komór, a nadto skrzyżowany poziomym otworem tętnicy głównej” [2]. W części dotyczącej morfologii prawej komory serca autor zamieścił najprawdopodobniej pierwszy w światowym piśmiennictwie opis tzw. dwujamowej prawej komory, dodatkowej anomalii towarzyszącej niekiedy zespołowi Fallota [2].

Oskar Widmann urodził się w 1839 r. we Lwowie. Ukończył szkołę średnią w Petersburgu. Studia lekarskie rozpoczął w Wiedniu w 1860 r., wkrótce jednak przeniósł się do Krakowa i na Uniwersytecie Jagiellońskim ukończył studia, a w 1866 r. uzyskał stopień doktora nauk medycznych. Jeszcze podczas studiów objął posadę asystenta w Katedrze Fizjologii Uniwersytetu Jagiellońskiego. W 1867 r. podjął pracę jako asystent na oddziale chorób wewnętrznych Szpitala Powszechnego we Lwowie, następnie próbował swych sił na oddziale chorób umysłowych, a potem w klinice terapeutycznej przy Lwowskiej Szkole Medyko-Chirurgicznej. W 1870 r. powierzono mu funkcję prymariusza w Iwowskim Szpitalu Powszechnym, a równocześnie w 1898 r. objął stanowisko kierownika Katedry Chorób Wewnętrznych Uniwersytetu Lwowskiego - początkowo jako docent, następnie jako profesor nadzwyczajny. Obie wymienione funkcje sprawował do końca życia.
Był wszechstronnym klinicystą i dociekliwym badaczem. Interesował się głównie anatomią i fizjologią układu nerwowego, chorobami zakaźnymi oraz układem sercowo-naczyniowym. Największą sławę przyniosły mu publikacje dotyczące schorzeń układu sercowo-naczyniowego. W pracach swych opisywał rolę mięśni brodawkowatych w czasie rozkurczu, niedomykalność zastawek żylnych bez zmian anatomicznych, a także nierównoczesny udział w skurczu serca różnych warstw włókien mięśnia sercowego.

W 1879 r. wydał pierwszy polski, jeden z pierwszych w świecie podręcznik z zakresu kardiologii: Choroby serca i tętnic w zarysie, po czym w 1884 r. dzieło znacznie obszerniejsze: Choroby serca i wielkich pni naczyniowych. Podręcznik ten był podsumowaniem całej ówczesnej wiedzy na temat patofizjologii wad serca, zarówno wrodzonych, jak i nabytych, tętniaków, procesów zapalnych i nowotworowych serca. W sposób nowatorski omówił choroby osierdzia, w tym rzadko spotykane wady worka osierdziowego.

Poza prostymi wadami jako jeden z pierwszych opisał ciężkie wady rozwojowe serca, np. przełożenie wielkich pni naczyniowych, atrezję tętnicy płucnej, niedomykalność i atrezję trójdzielną, zwężenie i atrezję lewego ujścia tętniczego, zwężenie ujścia mitralnego, zespół niedorozwoju lewego serca, i hipoplazję łuku aorty. Najbardziej nowatorskie jest omówienie patofizjologii wad rozwojowych serca o ciężkim, gwałtownym przebiegu klinicznym w okresie noworodkowym.

Najcenniejszym historycznie osiągnięciem Oskara Widmanna było opublikowanie w $1881 \mathrm{r}$. kazuistycznej pracy pt. Przypadek zwężenia tętnicy płucnej, która dotyczyła wady wrodzonej, współcześnie określanej „zespołem Fallota”. Praca ta wyprzedziła doniesienie Etienne Fallota i stanowi istotny, godny zapamiętania i cytowania, polski wkład w poznanie patofizjologii i anatomii zespołu Fallota, o czym chcieliśmy przypomnieć współczesnym klinicystom.

\footnotetext{
Piśmiennictwo

1. Fallot ELA. Contribution à l'anatomie pathologique de la maladie bleue (cyanose cardiaque). Marseille Médical 1888; 25: 77-93, 138-158.

2. Widmann O. Przypadek zwężenia tętnicy płucnej. Prz Lek 1881; 36: 469-472.

3. Evans WN. "Tetralogy of Fallot" and Etienne-Louis Arthur Fallot. Pediatric Cardiol 2008, 29: 637-640.
} 